\title{
AS CONFERÊNCIAS DO CURSO PARA PROFESSORES DO BARÃO DEGERANDO - 1839
}

Silvia Regina Cason CIVILIS/FE/UNICAMP silcason@yahoo.com.br

\section{CURSO NORMAL \\ PARA \\ PROFESSORES}

DE

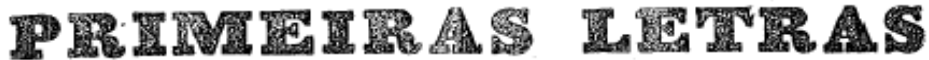

OU DHeCCŌES RELATIVAS A' EDUCAĢāo

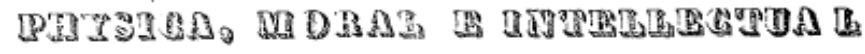

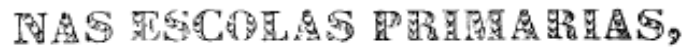

ERLO BSERO DEGERANBO,

IMPRESSO POR ORDEM

DO GOVERTO PROVIYCIAL DO RIO DE JANEIRO

PARA USO DOS PROFESSORES.

TRADIZIDO B ACCRESCEXTADO CON HCM APPENDICE DE LEIS GERALS i PROVIXCIAES SOBRE ESCOLAS.

$$
\begin{aligned}
& \text { IELO } \\
& \text { Woutor qoño Eandito rós Eveos o Sirr, }
\end{aligned}
$$

Natural da Provincia do Pará, Dignitario da Ordem do Cruzeiro, Lento que foi do Curso Jurielico de 5 . Paulo, Hembro das Sociedades Litteraria, e Auxiliadora da Industria, Secretario da Provincia do Rin Ir. Janeiro, Deputado da Assembléa Legislativa da mesma Provincis. Macist ado desde 23 de Agosto de 1819.

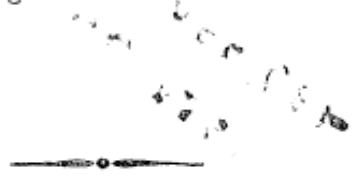

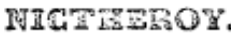

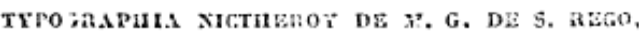

Praca Aunicipal.

1539. 
O documento, cujo frontispício é apresentado acima, trata-se do: Curso Normal Para Professores de $1^{a}$ s letras ou Direções Relativas a Educação Physica, Moral e intelectual. Nas Escolas Primárias - Pelo Barão Degerando - Impresso por ordem do Governo Provincial do Rio de Janeiro. Para uso dos Professores, Traduzido e acrescentado com um apêndice de Leis Gerais e Provinciais Sobre escolas. pelo Dr. João Candido de Deos e Silva. Nictheroy. Typographia Nictheroy de M.G. de S. Rego, Praça Municipal-1839; 421 páginas, que se encontra na Biblioteca Nacional do Rio de Janeiro, cujo original está na Biblioteca Nacional da França.

Meu primeiro contato com esse documento ocorreu por ocasião da escrita do meu TCC no curso de graduação em Pedagogia em 2011: “O ensino mútuo: uma inovação pedagógica do século XIX. Campinas”, orientado pela Prof ${ }^{\mathrm{a}} \mathrm{Dr}^{\mathrm{a}}$ Maria Cristina Menezes, do CIVILIS/FE/UNICAMP, que me emprestou o Microfilme que continha esse conjunto de informações. Por consequência, como naquele momento a cópia desse documento estava em microfilme somente podia ser devidamente explorado através dos equipamentos disponibilizados pelo Arquivo Edgard Leuenroth (AEL), do Instituto de Filosofia e Ciências Humanas (IFCH) da Unicamp. Por sorte, na ocasião, o mesmo foi gravado em CD pelos funcionários do próprio AEL/UNICAMP.

\section{O CURSO NORMAL PARA PROFESSORES DE PRIMEIRAS LETRAS DO BARÃO DEGERANDO}

No Brasil, o $1^{\circ}$ decreto de criação das Escolas de Primeiras Letras, de 15 de outubro de 1827, determinava que as mesmas fossem regidas, preferencialmente, pelo método monitorial ou mútuo. Os professores deveriam ensinar a ler e escrever, as quatro operações, princípios da moral cristã e da doutrina cristã; e deveriam punir segundo os "castigos lancasterianos". Recomendava-se também que os professores se preparassem pelo método mútuo de ensino, e estava previsto no decreto a sua instrução em curto prazo e à custa de seu ordenado nas escolas das capitais. Entretanto, não havia condições adequadas para a formação desses professores. A fim de sanar esses problemas foi criada a primeira escola normal do Brasil (1835-1851), na capital da província do Rio de Janeiro - em Niterói, com a finalidade de formar os futuros mestres no domínio teórico-prático do método mútuo. Devido à preocupação das autoridades em qualificar os professores com o que havia de mais moderno no concernente a este método foi traduzida a obra do Barão Degerando, em 1939, intitulada: 
"Curso Normal para professores de primeiras letras ou direções relativas à educação physica, moral e intelectual nas escolas primárias”; editada na França em 1832.

O Barão Joseph-Marie Degerando foi uma das grandes figuras da instrução primária popular no início do século XIX na França. Filantropo, dedicou-se à educação do povo, como forma de melhorar a espécie humana. Escreveu obras de filosofia, em que desenvolveu a ideia de que o homem poderia melhorar moralmente, através da educação; escreveu ainda obras de pedagogia sobre o ensino de surdos-mudos, a instrução de pobres, a educação moral e obras de caridade.

Tendo por objetivo formar o cidadão consciente de seus deveres, obediente à lei e capaz de submeter seus interesses individuais aos da nação, se questionava qual formação exigir de um professor do ensino mútuo. Degerando, nas conferências de seu Cours Normal, deu as diretrizes dessa pedagogia, ele se esforçou por persuadir os alunos mestres de que não deveriam ser simples professores de leitura, de escrita, de aritmética, uma vez que formariam a infância. Dessa forma, definiu a atividade dos professores não apenas como uma profissão, mas como um ministério moral. A ação moralizante do método mútuo, desenvolvida pelo trabalho dos professores, deveria alcançar também as famílias através das crianças. Deveria fazer desaparecer pouco a pouco o senso de ignorância e as funestas inclinações dos alunos.

Assim sendo, o decreto n. 28 de 11 de maio de 1839 determinou que se traduzisse e imprimisse a obra do Barão Degerando para uso dos professores de primeiras letras. Não se tratando de um livro, mas da publicação de um conjunto de dezesseis conferências, dirigidas aos professores de primeiras letras, descritas a seguir:

\section{Primeira conferência}

Dignidade das funções do professor de primeiras letras

Nesta primeira conferência o Barão Degerando (1839) reconhece a nobreza do título de professor primário desde que este cumpra com os deveres prescritos. Não se trata de uma simples profissão a se exercitar, mas de uma missão a se cumprir, uma função social a se executar.

O professor-leitor para quem ele dirige as conferências seria um tipo de magistrado cuja influência se estenderia para além da escola. Representaria os pais e em nome deles exercitaria o pátrio poder. Seu ministério se associaria como secundário ao ministério religioso: conquanto a instrução fosse útil à religião e à moral. Ao mestre caberia receber a criança em seus primeiros anos, ainda cheia de inocências para ser instruída no caminho da 
ciência e do bem. E a partir desses dons ela (a criança) poderia adquirir os demais. Assim, continua o autor, muitas gerações se sucederão ao redor do professor para aprenderem com ele, e sua influência também chegará às famílias desses meninos, consequentemente, acabará por envolver toda a sociedade.

O autor acredita que a missão de ensinar seja sagrada, pois que, bons costumes, indústrias, comodidade geral, paz, ordem pública, são frutos lentos, mas certos, vinda da boa direção dada à primeira infância, a educação geral. É uma profissão sagrada, pois aos professores cabe a missão de realizar o adiantamento da civilização. As nações desejam a melhoria da condição das classes trabalhadoras, uma vez que elas influem na consolidação e desenvolvimento de suas instituições e esta melhoria só poderá se alcançada pela propagação do adiantamento moral e da instrução. Esses alunos, destinados a vida de provações e suores, necessitarão de forças e paciência. Caberá ao professor torná-los virtuosos e armá-los de verdadeira energia de caráter. Requer-se do professor de primeiras letras que todo o seu tempo seja consagrado a esta missão. Requer o emprego combinado de todas as suas faculdades. Requer-se ainda paciência. Os meninos poderão ser ignorantes e indisciplinados e o professor terá que se adaptar a eles. Embaraços e dificuldades são esperados devendo ser superados com perseverança. Contrariedade e desgostos farão parte do caminho, porém os professores deverão encontrar em si mesmos recursos para seguirem adiante.

Degerando (1839) expõe que se junte à sólida instrução também talento de ensinar, para orientar os alunos e formar bons costumes. Para tanto, diz que, em troca de tudo quanto será exigido, muito pouco será oferecido. Um dia (no futuro) a maior recompensa virá dos próprios alunos depois que tiverem saído da escola, por terem recebido do professor a melhor instrução; eles o considerarão um amigo, um guia cujos conselhos mostraram-se valiosos. Já no fim da vida, estes mestres estarão cercados por pessoas a quem tiveram feito o bem. Em tal caso, serão tomados por um único sentimento, o de reconhecimento.

Trata-se de uma profissão que oferece constante ocasião aperfeiçoamento e fornece meios para isso. O professor terá que estudar ininterruptamente, terá assuntos de observação, e ao buscar melhorar os discípulos e fazê-los bons, também ele, o professor, se melhorará.

As funções que serão desempenhadas pelos professores já foram elaboradas/pesquisadas por sérios educadores que buscaram aperfeiçoar os métodos que usaram. Personalidades renomadas trabalhando para os mestres e para a infância, alguns publicando tratados, instruções e manuais para os mestres das escolas elementares, como na Inglaterra os doutores Bell e Lancaster, na suíça Pestallozzi voltando a vida à reforma da educação em todas as classes, desde as primeiras instruções dadas pela mãe até a que introduz 
nas ciências, e aplicando-se a desenvolver a inteligência pelos exercícios da instrução. Na frança, no fim do século XVIII o cônego de La Salle erigiu um instituto especial para direção das escolas primárias, criou o método simultâneo que lutou durante vinte anos para fazer triunfar a boa causa da educação elementar.

Dessa forma, os futuros professores, no exercício de sua tarefa/missão, estarão assistidos por estes brilhantes homens das letras, que os ajudarão a desempenhar dignamente suas tarefas.

\section{Segunda conferência}

Disposições e qualidades necessárias ao professor de ensino primário

Ao se abraçar qualquer carreira, antes é preciso saber quais os motivos levam a escolhê-la. Para seguir na carreira de professor é necessária vocação especial, pois, trata-se de exercer funções de poderosas influências. $\mathrm{O}$ autor aconselha que, o professor que tentasse essa carreira com interesses/especulações mercantis ignoraria o verdadeiro caráter dela, não se sairia bem porque não entraria em suas funções com o espírito que ela requer. O professor interesseiro não poderá desenvolver com seus discípulos relações morais, não poderá fazer com que o amem e respeitem. Degerando (1839) deseja que a carreira de professor seja abraçada com verdadeira afeição, que entrem nela com sacrifício para desempenhá-la com brio.

Muitas condições são necessárias para formar o bom professor. Primeiro é preciso gostar das crianças e de viver no meio delas, este será o mais certo sinal de vocação. Este é o segredo para poder bem dirigi-los, mas mais que isto, o sucesso do professor depende principalmente de seu caráter. $\mathrm{O}$ autor diz que castigos poderão ser aplicados, regras recompensas, mas nada poderá superar a autoridade invisível de seu caráter pessoal. Esses mestres estarão cercados de crianças de tenra idade, talvez acostumados a vida vagabunda e dissipada que talvez não entendam seu raciocínio, no entanto, eles sofreram as influências de seu caráter. Convém que nunca demonstrem capricho ou fraqueza, a criança observa seu mestre com atenção por estar dependente dele. Se o professor não souber se conter, o aluno descobrirá que tem poder sobre ele e não o obedecerá. Porém se ele sempre for o mesmo, não se alterando, os alunos o respeitarão e seguirão com confiança. É preciso que tenha igualdade de caráter, primeira qualidade exigida dos que trabalham com crianças. "As crianças mais cedem, as forças do exemplo do que entendem lições: a imitação lhes serve de raciocínio" (DEGERANDO, 1839, p. 27). 
O Barão Degerando (1839) indica um infalível segredo para conquistar consideração: Obter estima geral, fugir das relações de intimidade, nunca tomar parte em desavenças, nem participar de disputas por interesses pessoais, conservar natural dignidade. O professor deve ter vida pura, não deve se expor em relação a suspeita sobre o respeito dos bons costumes. Ao aspirante ao nobre emprego de professor é necessário que seja homem de bem. Seu primeiro ensino são seus exemplos. Às crianças poderá exigir aquilo que for o primeiro a fazer. Dessa forma, o professor que tem de velar constantemente sobre os discípulos, com a mesma assiduidade com que deve fazer sobre si mesmo.

É preciso que o professor tenha determinados conhecimentos - Não basta que saiba para seu uso, é preciso que saiba para ensinar, as ideias que terá que transmitir deve ser-lhes familiar. Deverá compreender o porquê de cada coisa.

Na instrução tudo depende dos primeiros elementos: se o menino bem os entender,
adiantar-se-há com rapidez; no caso contrário, as noções falsas ou confusas que
houver concebido desde a entrada servir-lhe-ão de embaraço ao que devia ser
introdução. Requerem, portanto esses primeiros elementos certeza e exatidão
perfeitas. (DEGERANDO, 1839 , p. 35 ).

Talvez digam alguns que se guiam pelo método do ensino mútuo. Todavia, neste ponto, o autor critica esse método, dizendo ser grave inconveniente de tal método, porque privaria os professores das utilidades que devem colher do comércio com os discípulos e da influência que seu caráter pessoal devia ter sobre eles.

\footnotetext{
O ensino mútuo obriga o aluno a fazer todo o uso possível de suas forças, procede por mecanismo graduado, por meios gerais que não requerem ação tão direta, frequente e individual do Mestre sobre cada discípulo, e é por isso que ele permite obrar sobre maior massa; mas nem por isso devem os olhos do mestre ser menos constantemente dirigidos ao mesmo tempo a todos e a cada um de seus alunos; cumpre que possua uma espécie de habilidade diferente da que é necessária no ensino individual; mas é de mister esta atividade em grão eminente. Por outro lado, os cuidados que o professor deve aos discípulos na Escolas d' ensino mútuo não se limitam á simples direção dos exercícios gerais, que tem lugar durante as classes. (DEGERANDO, 1839, p. 38).
}

Os dias do professor são cheios, os meninos correm com alegria para junto dele. A escola parece um pequeno mundo, onde reinam ordem, prudência e bondade. Os discípulos por eles formados, na idade adulta, trabalhando em diversos ofícios, quanto mais aproveitarem de suas lições mais gratos lhes serão, pontua o Barão Degerando (1839). 


\section{Terceira conferência}

Educação nas escolas primárias

Nesta parte o termo educação é substituído por instrução. O autor pede cautela quanto ao erro geralmente propagado em relação à instrução, de que seja o único benefício que a infância tira da escola. Para ele educação e instrução são elementos inseparáveis de um mesmo sistema, e a instrução está subordinada à educação. Talvez fosse por isso que quando uma escola era aberta só se ensinava a ler escrever e contar. A tarefa do instrutor se baseava em formar a infância do homem, desenvolver-lhe os dons da humanidade.

Educação e instrução caminham juntas, se privadas de seus mútuos auxílios cada uma perderia uma porção de sua utilidade. A instrução não existiria apenas ao receber lições, e ao se ler livros, ela acontecerá pelo exercício e desenvolvimento das forças próprias da inteligência as quais favorecem a observação, a compreensão, a comparação, o julgamento e aplicação. São as forças interiores do espírito e são estas capacidades intelectuais que a educação deseja cultivar. Uma criança de afável temperamento é mais aplicada e está menos exposta à dissipação, e o exercício religioso é capaz de trazer efeitos vantajosos para a vida moral.

As crianças após assistirem as lições do dia voltavam para suas famílias. Sendo educados na casa paterna e para a escola apenas vinham para buscar instrução. De fato, a educação doméstica muito contribuía para a formação desses meninos, mas não os dispensava da porção mais essencial de seus ministérios. Essas horas passadas na escola eram alimento moral para todo o dia. Depois de tê-las passado junto de honrado professor, voltavam para o seio da família, conservando os frutos das boas influências que colheram, e seus exemplos, desejava-se, atingisse também os pais.

Acreditava, portanto, o Barão Degerando (1839), que os cuidados do professor não se limitavam apenas dentro da escola, e que suas funções iniciavam e acabavam com a classe.

Para o autor, a educação deveria ensinar a viver ao longo da existência humana, habilitando o homem a ser útil aos outros e a si mesmo. Assim, em sua colocação aventa que durante o curso da carreira terrestre deve a educação ser de continuado progresso, bem como o término dela deve ser de grande transformação. Havendo para o homem dois tipos de educação: uma que ele recebe dos outros e outra que ele oferece a si mesmo. Quando termina a educação que ele recebe do mestre, terá que continuar sozinho os progressos que a principio eram alcançados com a ajuda do professor. Quanto mais ele conseguir essa autonomia, tanto melhor terá sido o papel que o professor desempenhou. 
Acrescenta que há uma educação primária assim como há uma instrução primária. Uma introduz na vida a outra na ciência. Da mesma forma que a instrução primária recebe o aluno ainda destituído de ideias e conhecimentos, a educação primária o recolhe quase sem inclinações, hábitos e capacidades. "Não há uma educação especial para o povo, tampouco uma moral a parte para ele, há, pois, somente uma educação particular para certa idade da infância, e para certas condições da sociedade" (DEGERANDO, 1839, p. 53).

A educação se divide em três ramos: Physico, moral e intelectual. $\mathrm{O}$ autor nesta parte volta a tratar da importância da educação infantil. Fala da grande utilidade que ela representa para aquele que a recebe, sendo muitas vezes o único fiador de seu futuro porque determina sua moralidade, fortifica-os nos princípios que os devem guiar, compõe seu patrimônio mais real. "A quem houver faltado esta assistência se verá submergido em completa inutilidade, que será uma espécie d'idiota, impróprio para tudo, pesado a si e aos outros" (DEGERANDO, 1839, p. 56).

\section{Quarta conferência}

Educação physica

Para Degerando (1839), a educação física é aquele ramo da educação que tem por essencial formar os diversos órgãos do corpo. Procura dar aos meninos boa saúde e desenvolver-lhe as forças mecânicas.

Dentre os cuidados que se aplicam ao corpo, alguns terão influência moral. Assim, o menino que demonstrar falta de asseio será menos favoravelmente acolhido nas festas, nas solenidades e nas celebrações religiosas. Caberá aos professores dar as contribuições para moderar neles as grosserias do trato, ou seja, a serem mais adequados socialmente, limpos e alinhados. Se conseguir isso com a maioria, os demais os imitarão.

Para conservar a saúde dos meninos nada era mais indicado do que exercícios moderados, variados e regulares. Os movimentos dos diferentes membros e a postura do corpo requerem do professor atenção continua; os meninos não devem ficar muito tempo sentados, alternadamente devem ficar em pé, andar, mover os braços, mãos e cabeça. Para isto o Sistema praticado em nossas escolas de ensino mútuo serve engenhosamente.

Regra Geral: fazer alterar sucessivamente o movimento e o repouso, as diversas espécies de movimentos e posturas durante a classe; não deixeis prolongar nenhum desses estados além de meia hora, fazei-os cessar no momento em que o aluno estiver fatigado. (DEGERANDO, 1839, p. 61-62). 
Aqui podemos notar a estreita relação entre a physico e a moral: pois,

[...] o discípulo que sente fadiga já não tem a mesma liberdade de espírito, o mesmo gosto ao trabalho; a atenção se lhe escurece; inquieta-se, agita-se; irrita-se contra a disciplina, e atormenta os companheiros. O professor, então, castiga sem razão, agrava a situação, quando deveria livrar o menino desses constrangimentos inúteis. (DEGERANDO, 1839, p. 62).

$\mathrm{O}$ autor acredita que muitos professores erravam nesta parte porque buscavam dos alunos uma imobilidade passiva que só os contrariavam e irritavam. Deles, pede-se que vigiem o porte de seus discípulos, evitando que fiquem curvados, em má postura, a que estão sujeitos a adquirir quando ficam largados a si mesmos. É preciso regular-lhes o andar, observar como movem os braços e as mãos, pois, todos estes detalhes têm sua importância.

Para alcançar este intento propunha que sem muitas despesas o professor poderia mandar um carpinteiro fazer "um mastro ou escada perpendicular ou duas travessas horizontes e paralelas, assentadas em quatro estacas na altura dos cotovelos: ali os discípulos poderão pular, suspender-se, e fazer diferentes voltas, mas tudo em ordem, procedendo sempre do mais simples para o mais dificultoso" (1839, p. 64). Os meninos poderão se exercitar durante o horário do recreio, ou seja, uma ótima ocasião para o mestre trabalhar na educação physyca com bons resultados para a educação moral.

Sobre os jogos, o Barão Degerando (1839) diz que são os mais importantes para a infância. Sendo importante que todos os alunos participem da "recreação animada"; em que os movimentos são mais vivos, rápidos, enérgicos e variados. Devendo ocorrer ao ar livre, sempre que possível, conservando a agilidade através dos saltos, favorecendo o uso do pião e do laço, do arco, do papagaio e de tudo que desenvolva a destreza. Atrelado às todas essas atividades é importante que se tenha um objetivo determinado. Dessa forma, o professor conseguirá melhores rendimentos dos alunos em vistas de que, basta uma mudança de ocupação para aliviar-lhes e reanimar-lhes as forças, principalmente quando o trabalho com o corpo suceder a aplicação mental e vice-versa:

Vimos no belo instituto de Mr. De Fallenberg, em hofwyl, os meninos que voltam do trabalho do campo, correr com alegria às lições que os instruem e lhes nutrem o entendimento; vimo-los ao sair das classes tornarem com ardor aos instrumentos agrícolas. (DEGERANDO, 1839, p. 65).

Recomenda, ainda, que os alunos sejam levados em passeios algumas vezes, assim se exercitará a vista, acostumar-se-ão a observar e a comparar. Embora todos os alunos vejam as mesmas coisas, nem todos enxergam da mesma forma. $\mathrm{O}$ menino que olha ao acaso, não saberá fazer uso dos olhos, se tornará incapaz de refletir. Sugere, então, que o tom da voz do 
mestre e do aluno seja sempre medido, simples e harmonioso. Fugindo de gritos tumultuosos, ásperos e discordantes. Assim, o exercício do canto, o estudo de música simples são necessidades reais e universais da educação elementar. A música cultiva a atenção e provoca uma série de comparações exatas e precisas. Portanto, a palavra e o canto, favorecem os exercícios dos pulmões. Neste sentido formam parte da educação physica. A música tem o poder de auxiliar todos os movimentos musculares e facilitam a ação dos órgãos. $\mathrm{O}$ soldado que marcha cantando vai animado de maior ardor e sente menos fadiga, conclui.

\section{Quinta conferência}

Educação intelectual; e primeiramente como pode a professora cultivar a atenção, imaginação e memória

Os efeitos da educação intelectual, ao contrário da educação física, são menos perceptíveis aos olhos. O autor propõe um resumido curso de filosofia para mestres de primeiras letras, para ajudar no entendimento do gênero da cultura do qual se poderá tirar varias utilidades a diferentes respeitos.

A atenção é de fundamental importância para o sucesso na aprendizagem. O professor que não souber despertá-la nos alunos, o será apenas no nome. Essa atenção que ele terá de despertar nos discípulos ainda não existe neles, o mestre é que tem a obrigação de fazê-la aparecer. As inteligências a ele confiadas, estiveram vagando sem desígnio, lançando os olhos aqui e ali apenas para a superfície das coisas, não notando nem parando sobre coisa alguma. Os meninos das classes trabalhadoras, até o momento de irem para a escola viveram uma existência monótona, carente de relações sociais, são pouco curiosos, por quase desconhecerem os prazeres da curiosidade. O primeiro trabalho do professor é saber tornar atento o menino. É preciso acordar essa atenção, e guiá-la, através de indicações da natureza.

A curiosidade pode ser excitada através de tudo que cause surpresa, através de impressões fortes e objetos novos, expõe o autor. Essas escolas tristonhas em que as lições são dadas de forma monótona, em que aluno nada tem que desejar e buscar, quase que aniquila a curiosidade da infância, porém, ao contrário, naquelas escolas em que logo à entrada se oferece algo de engraçado e risonho, o aluno novo vê seus companheiros correrem com prazer e aplicarem-se aos trabalhos com alegria; tudo corre para colocá-lo em expectativa e logo querem se juntar aos colegas. Mas neste decurso, aproveitando a recreação, o mestre deverá criar milhares de ocasiões inesperadas, que inspirem aos meninos o desejo de observar, e a necessidade de perguntarem. Muitas vezes sendo questionados a respeito do que 
souberem, notarão o que ignoram, e assim serão incitados a procurarem a aprender. A este respeito o professor terá vários recursos ao redor de si: os objetos simples e familiares; as produções da natureza; as obras de arte; as corriqueiras ações da vida etc. Estes são exemplos que podem ser utilizados para capturar a atenção dos alunos e proporcionar ocasiões em que possam querer saber os porquês e os como. Nada aguça mais a curiosidade do que dar a entrever apenas a metade do que se propõe a mostrar, e deixar um lado escuro junto daquele que se descobriu. Há para isto dois meios: separar do aluno aquilo que só serviria para distraílo e apresentar aquilo que deveria ocupá-lo. Degerando (1839) propõe que sejam empregadas frequentes comparações para que sirvam de discernimento. Será preciso renovar essa curiosidade, apresentando a matéria de diversas formas e explicando-as em todas as particularidades. Para conquistar a atenção do aluno é necessário deixá-lo de modo que se sinta tranquilo, que nada o atormente, nem hes fatigue as forças, nem o moleste ou o agite. Aos mais adiantados deve-se requerer mais, mas aos que principiam convém abrir estrada larga e cômoda.

Com crianças mais novas será indispensável manter ativo o interesse da curiosidade. Não expondo todas as miudezas práticas, mas indicando o espírito delas, e transferindo ao mestre o cuidado de pô-las em prática. E acrescenta que o

[...] "ensino mútuo" (que está organizado entre eles) dá muitos exemplos engenhosos. Aqueles quadros suspensos em roda das salas; aqueles telégrafos na extremidade dos bancos; aqueles diversos instrumentos preparados; a postura dos Monitores; o assobio que avisa; as ordens dadas; tudo isto são outros tantos aguilhões que provocam à curiosidade os meninos. (DEGERANDO, 1839, p. 85).

Exercitando os meninos na escrita, se pedirá para escreverem, ao invés dessas palavras insignificantes, alguma palavra ou frase que recorde ideia familiar e interessante, eles terão gosto em fazê-lo. Para afeiçoar o discípulo ao seu trabalho o mais útil é fazê-lo feliz por todos os meios que lhe deem felicidade real e pura, propõe o autor.

Há duas diferentes qualidades na atenção: uma que abarca os detalhes, outra que abarca o todo. Recomenda o Barão Degerando (1839) que não convêm aplicar o mesmo regime a todos os alunos, pois alguns a exercitam mais facilmente, mas é breve; outros só prestam atenção a custo, mas uma vez fixada, perseveram com maior constância e afinco. Convém moderar com os primeiros e animar os segundos. No entanto, o mais importante é que os meninos sejam exercitados a serem senhores de sua atenção e a disporem dela como instrumento de seu uso. Tão relevante quanto a atenção são a imaginação e a memória. A memória suscita o passado, recebe em deposito as aquisições do espírito e a imaginação concebe o futuro, reveste a vontade com mil cores o objeto a que aspira. A maior parte dos 
professores sequer sonha que a imaginação dos seus alunos guarda alguma cultura. Preocupam-se com os perigos que a imaginação expõe os homens e não descobrem nela mais que fonte de extravagância e delírio. Aos futuros mestres, ouvintes destas conferências do Barão Degerando, (1839) pedia-se que abandonassem estes erros tão comuns. Todos os dons com que a Providencia Divina enriqueceu o homem são úteis, apenas os abusos é que são perigosos, dizia. A imaginação abre novos horizontes tão necessários à previdência e ventura do homem.

$\mathrm{O}$ autor prossegue explanando que em muitas ocasiões, os mestres de ensino primário, receberão discípulos cujos espíritos estejam em espécie de letargo e a imaginação tenha se extinguido, acometidos da pobreza e da humilhação. Então, estes mestres terão que reanimar o foco da vida intelectual nessas criaturinhas, tão cedo atacadas da adversidade. Sugere, para tanto, que para cultivar e dar a melhor direção à imaginação, preservando-a dos desregramentos, o segredo é fácil e simples:

[...] fugi da uniformidade que entristece, atormenta e cansa; rejeitai tudo que puder causar desgosto: cuidai em promover no vosso aluno o sentimento do belo; ofereceilhe aos olhos cores risonhas; aos ouvidos melodiosos sons; dispondo os objetos em formas regulares, elegantes e engraçadas; exercite-se o menino a si mesmo em reproduzi-las. Exercitai-lhe a indústria; animai-o a por si mesmo a entrar em ação, em ensaiá-la e inventar em espera sem dúvida limitada, mas, todavia inesgotável para ele, onde se pode divertir e brincar, porque para ensaiar e descobrir será mister que combine. Propondo-lhe problemazinhos a seu alcance; para resolvê-los será necessário que imagine. Desenrolai diante dele quadros descritivos, escolhei narrações engenhosas, pitorescas, animadas, porém verdadeiras e simples [...]. (DEGERANDO, 1839, p. 90).

Para cultivar a associações da memória nos alunos, crê o mestre ignorante e preguiçoso, não há coisa melhor do que a frequente repetição. Mas isto não é mais que um efeito mecânico. Se a associação, na origem, for ajudada pela analogia, poupará grande parte da repetição que foi necessária. Obrigando o menino a repetir, evitaremos que reproduza as coisas sempre pela mesma ordem, é preciso acostumá-los a variar e mudar as combinações. Os professores devem estabelecer associações principais, ligar os objetos entre si por meios de variadas relações. A música também auxilia eficazmente ao exercício da memória, ressalta. 


\section{Sexta conferência}

Continuação da matéria antecedente - Como pode o professor de primeiras letras formar o juízo e a razão de seus alunos

A falta de juízo é pior que a ignorância, pois corrompe a mesma ciência. O professor de primeiras letras tem especial importância na formação desta virtude em seus discípulos. A observação é que forma o juízo relativamente ao conhecimento dos fatos. Portanto, Degerando (1839) propõe aos futuros mestres que deixem os meninos observarem, mas evitem que fiquem apenas nas primeiras aparências e façam com que observem com ordem, perseverança e notem o que observam. Para se certificarem de que o menino observa, convidem a contar o que viu. Isto fará com que ele se dedique a observar ainda melhor. É importante fazer com que os discípulos notem, desde cedo, como se encadeiam os acontecimentos, que identifiquem quais são as conexões entre efeito e causa. Assim, se formará principalmente o seu juízo, habituando o menino a indagar e entender o porquê de cada coisa. Para isto, não será necessário mudar de cenário. A pessoal experienciazinha de cada momento ministrará, ao menino, abundantes conteúdos para este gênero de indução.

Os professores não devem aplaudir os meninos que se antecipam em dar explicações frívolas. Arriscando-se em falar a torto e a direito a respeito do que não entendem. Os mestres precisam proceder com cautela, se querem que os meninos adquiram juízo sólido. Estes aprendizes deverão observar por si mesmos a exatidão dos fatos, só assim estarão aptos para julgar. É útil que o aluno seja incentivado a resumir as circunstâncias que observou, e enumerá-las para verificar se algo lhe escapou. Como já foi dito, é recomendado que o menino seja chamado a julgar somente aquilo que esta a seu alcance. Uma vez que, ainda esteja alheio de toda instrução. O menino deverá ser conduzido de forma a perceber se bem entendeu ou se enganou assim ele poderá cometer alguns erros, mas depois os reconhecerá e retificará.

\footnotetext{
Aqui entra outra conveniência do sistema mutuo: $O$ menino encarregado de dirigir outro, por isso mesmo se exercita em refletir e entrar em si, e assim se torna mais capaz de guiar-se; pois não poderá apontar ao camarada, o que este deve fazer, sem que a si mesmo pergunte como obraria em caso igual. O emprego do Monitor é tirocínio para a razão. (DEGERANDO, 1839, p. 117).
}

Aos que acharem que muito se está pedindo para uma escola de primeiras letras, o autor responde que as chamadas operações mecânicas de ler e escrever requerem exercícios corporais, serão melhor executadas quando não forem meramente mecânicas e sim ajudadas 
pelo concurso da inteligência. A instrução na escola de ensino primário pode e deve ter maior abrangência do que comumente se supõe - este será assunto para a próxima conferência.

\section{Sétima conferência}

Continuação do precedente assunto - Instrução nas Escolas de Primeiras Letras

Segundo Degerando (1839), são duas as relações para a instrução nas escolas de ensino primário ao se atender as necessidades dos meninos que nela vem buscar: as necessidades pertinentes à sua idade; e as relativas às condições a que são destinados.

$\mathrm{Na}$ primeira relação, a escolas de ensino primário devem oferecer os primeiros e mais simples elementos de educação. Com metas determinadas, tanto pela capacidade do aluno, quanto pelo tempo que ele deverá permanecer nela. Na segunda, a escola deve oferecer os conhecimentos indispensáveis a todos, deve preparar esses meninos pobres para a penosa vida que os aguarda. A instrução deve limitar-se aos conhecimentos elementares, pois que se ultrapassarem estes limites a criança a receberá incompleta e superficialmente. O autor justifica estas colocações, alegando que "o conhecimento quando dado a quem, por seu destino, não é chamado a usar deles só servem para perturbar o espírito, inspirar desejos inquietos e sugerir pretensões impossíveis de satisfazer" (1839, p. 122).

A instrução primária nas escolas, conforme o Barão Degerando (1839), se divide em dois ramos: conhecimentos - que ensina máximas de moral, princípios religiosos, geografia, história, elementos de história natural, de geometria, pesos e, artes que ministra instrumentos de leitura, escrita, gramática e cálculo, desenho, cantoria, agrimensura e ginástica. $\mathrm{Na}$ sequência, descreve a utilidade e a importância de cada uma dessas áreas, mas aqui não nos deteremos a elas. Declara ainda, que, há duas espécies de ignorância, ora desconfiada, ora presunçosa. A ignorância desconhece as causas reais dos acontecimentos e adota explicações com suposições arbitrárias. "A fé na feitiçaria não será consequência da ignorância das leis mais simples da natureza? Será outra coisa a superstição mais do que a ignorância das verdadeiras relações entre o homem e o seu criador?" (DEGERANDO, 1839, p. 137).

Nesta parte da conferência o autor reforça a importância da missão dos professores. A única forma de prevenir a sociedade destes males é preveni-la desde a origem. Deve-se ensinar aos alunos que tudo é regido por leis certas, constantes e gerais emanadas da suprema inteligência. Dar-se-ia profundo convencimento desta verdade mostrando todos os dias, que os acontecimentos mais extraordinários são efeitos de leis ordinárias. 
Questiona quanto ao tempo de permanência dos meninos na escola como insuficiente para tantas coisas. Trata-se de um erro o professor de ensino primário acreditar que tenha concluído seu papel depois de ter distribuído o trabalho, dado os sinais, dirigido os monitores, velado na ordem, dirigido os movimentos, pronunciado os castigos e decretado os prêmios. Será necessário desenvolver com os alunos práticas livres e familiares que tenham por objeto estimular e satisfazer as curiosidades dos alunos.

Ao concluir esta matéria, o autor faz uma observação: para que a instrução seja sempre saudável é necessário cuidar para que nunca se apresente aos meninos como instrumento de vaidade, que se apresente como objeto de melhoria e nunca como objeto de ostentação, que aprenderão para uso próprio e para ser útil aos outros, mas nunca com o objetivo de dominação. A verdadeira instrução torna o homem modesto porque lhe mostra que ainda ignora muitas coisas.

\section{Oitava conferência}

Continuação do mesmo assunto - Método na Instrução Elementar

De acordo com o autor, os systemas gerais que presidem à organização das Escolas de Instrução Elementar se referem a três formas principais: ensino individual, simultâneo e mútuo. No ensino individual cada aluno recebe diretamente as lições do professor; ainda que haja grande número de alunos na mesma sala, são poucas as orientações que o mestre dá em comum, ele vai de um em um, passando a lição e a corrigindo. No simultâneo, o professor instrui e dirige ao mesmo tempo certo número de alunos, através do mesmo sinal e da mesma palavra, e os alunos executam as mesmas coisas ao mesmo tempo. Entretanto, como nem todos os alunos da escola tem a mesma capacidade, nem começa no mesmo dia tão pouco se adiantarão tão rápido, a escola está dividida em certo número de classes nas quais os alunos são distribuídos segundo suas capacidades. Neste ensino (simultâneo) como no individual estabelece relação direta entre o mestre e o discípulo.

O ensino chamado mútuo interpõe entre mestre e discípulo certo número de monitores, tirado dentre os mesmos alunos: por este meio permite fazer com que desapareça a separação das classes, e se introduza na mesma classe muitas subdivisões, que não sofria o ensino simultâneo. Permite também individualizar a direção e a vigilância, sem transtornar a harmonia do todo. (DEGERANDO, 1839, p.146).

O ensino simultâneo foi criado pelo cônego Lasalle. 
O ensino mútuo havia já sido praticado pelos antigos, recomendado na França pelo Sabio Rollin, executado em Paris desde o século passado por Herbault, pelo Cavalheiro Paulet, pelo bom padre Gaultier, que de novo descobriu na Inglaterra o princípio em que se funda este ensino. Organizaram Bell e Lancaster este systema em duas diferentes formas, desenvolveu-no em maior escala, e ali foi estudado por alguns franceses filantropos que o trouxeram para o meio de nós. Brevemente em 1815, foi naturalizado na França com diversas modificações [...]. (DEGERANDO, 1839 , p. 145-146).

$\mathrm{O}$ autor segue comunicando que a individualidade no ensino (método individual) apresenta uma vantagem: permite adaptar o ensino às capacidades do aluno e proporcioná-lo constantemente a seus progressos. Como o mestre tem de repartir seus cuidados com certo número de alunos, cada aluno tem de ficar entregue a si mesmo por certo espaço de tempo, privado de direção e vigilância. O número de alunos é limitado, pois tanto maior o número maior o tempo em que ficará aguardando o mestre lhes dedicar atenção.

O ensino simultâneo é superior ao individual, pois o mestre do método simultâneo se dirige a classe toda, que o ouve. Há, portanto, maior rapidez nas operações, pois o tempo e as forças do mestre são distribuídos com maior economia e a harmonia de seus trabalhos mantém a todos em natural disciplina. O problema, no entanto, está em classes numerosas em que os alunos não estão no mesmo nível de adiantamento; os mais fracos ficam para traz e os mais adiantados são convidados a parar para esperar seus companheiros.

\footnotetext{
O ensino mútuo obtém maior simplicidade e economia de meios; porque um único mestre basta para todas as divisões da escola, e nós vemos até quinhentos discípulos com um único professor, sem a menor confusão, incerteza ou demora. O ensino mútuo, pela classificação que introduz nos discípulos, permite distribuí-los segundo seu grau exato de capacidade atual. Reúne à simultaneidade na direção e vigilância geral verdadeira individualidade de ação da parte de cada aluno: observa cada aluno - seus iguais e é por este observado; o menino tem que empregar a todo momento todo esforço de que é capaz; sobe, desce, torna a subir ao nível de seu merecimento. Reúne por tanto este ensino ao mesmo tempo os proveitos da simultaneidade e os da individualidade; tira de um a simplicidade das molas, e do outro a energia da ação, e tem o eminente mérito de chamar cada menino constantemente a fazer uso de suas forças. (DEGERANDO, 1839, p. 147-148).
}

Nos dois primeiros modos de ensino o professor conserva relações mais diretas com os alunos. No ensino mútuo sua ação é menos imediata,

[...] ele obra pelo órgão dos monitores, nele respira e por eles se multiplica; é ele quem os forma e dirige. $\mathrm{O}$ aluno no exercício de monitor recorda o que já aprendeu e dá conta disso a si mesmo: assim se confirma e aperfeiçoa no que já sabe. As trocas que se efetuam entre os alunos duplicam as forças de cada um. (DEGERANDO, 1839, p. 148).

O método deve estar, por um lado, em conformidade com a lição ensinada, e por outro, com a disposição de quem estuda; e o melhor método é aquele que melhor satisfaz estas duas condições. O professor que bem souber o que ensinar e a capacidade do discípulo que 
instrui, por si mesmo achará o método conveniente. Há métodos de classificação e métodos de dedução. $\mathrm{O}$ método tem dois fins: Ao mesmo tempo em que deve conceder às disposições infantis todas as atenções necessárias, não deve conceder coisa que passe além. Não é o melhor método o que ensina o menino a conseguir instrução, mas aquele que o força a estudar, ajudando-o no estudo, diz o autor. O método para o mestre deve ser assistência e não prisão, não devem se sujeitar a ele com cega rigidez, mas usá-lo livremente e acomodá-lo às circunstâncias.

O método da Intuição - oferece a "coisa" em lugar da definição, os fatos em lugar das convenções.

O método usado por Pestalozzi para ensinar aritmética, em lugar de noções abstratas de números, e de fórmulas que exprimam suas relações, mostra aos meninos as mesmas quantidades, personalizadas em objetos semelhantes, que são fáceis de contar a primeira vista. Usando de tabuleiros eles decompõem da mesma forma que compuseram as quantidades de bolas, somam e diminuem. Pode-se obter o mesmo resultado com qualquer outra coisa, pãezinhos, linhas de diferentes tamanhos e cores. Portanto, pelo método da intuição, segundo Degerando (1839), se forma a educação do bom senso. Exercícios de intuição dão condições para o aluno a passar sem mestre, e nesta necessidade se acham a maior parte dos meninos das escolas de primeiras letras.

No passado o ensino se dava através de perguntas e respostas. O autor aconselha que é importante deixar o menino perguntar, por que isto é próprio de quem ignora e deseja saber. Quando o aluno fizer perguntas fora de propósitos, convém mostrar-lhe que se afasta de seu caminho ou que aspira saber o que está acima de seu alcance. Um novo método se faz; quando o professor perguntar a seu aluno e ele não souber responder, significará que as explicações dadas não foram suficientemente claras ou que o menino ainda não está pronto para elas, ou então não a assimilou. Neste caso, o mestre tem que rever suas explicações.

\section{Nona conferência}

Educação moral nas Escolas de Primeiras Letras

Segundo o autor, a educação moral domina toda educação do homem, uma vez que forma o caráter, faz frutificar a educação física e intelectual. Como o menino imita tudo o que vê, convém que lhe seja dado bons exemplos para imitar. Aos irmãos mais velhos, que já frequentam as escolas, é preciso ensinar como devem se portar com os irmãos mais novos, para que os mais velhos, de certa forma, ensinem os mais moços também. 
Degerando (1839) recomenda que se façam salas de asilo para a infância - para que a primeira idade (da infância) goze dos benefícios da boa educação. Os meninos que chegarem para os cuidados do mestre e que já possuírem os cuidados maternos necessitarão que o mestre apenas continue o trabalho já iniciado. Mas haverá aqueles cujos pais não tiveram tempo, vontade ou capacidade para se dedicarem a eles, nestes já terá se instalado a educação da desordem e do vício; neste caso caberá ao professor destruir os hábitos adquiridos e purificar as maculas. "O menino desprezado não só fica para trás, como é impossível que não ganhe alguns defeitos: no desamparo em que é deixado, o egoísmo e a preguiça se aproveitarão da ausência de toda boa direção ou vigilância" (DEGERANDO, 1839, p. 179180). O primeiro trabalho do professor ao receber estes discípulos é estudar o estado em que chegam e depois curar o passado e procurar fazê-los melhores para o futuro. Tudo isso com a compreensão do professor, pois estes meninos não têm culpa dos males que os outros lhes causaram.

Entre os meninos que frequentam as escolas de primeiras letras alguns poderão estar abatidos por cedo terem sidos expostos às humilhações da condição pobre e de condição dependente. Longe de serem acometidos pela ambição de dominar, são acometidos pelo desalento. Estes deverão ser relevados aos seus próprios olhos, restituindo-lhes a confiança em si mesmos - profere o Barão Degerando (1839) aos seus professores-leitores. Assim, irão obter dos companheiros o respeito que merecem, e ao menos na escola esquecerão as desgraças que lhes pesam oriundas da condição social a que estão submetidos. Estes são um dos mais sagrados objetivos da atenção do professor para com seus alunos. E se alguma diferença se fizer, esta deverá ser toda em favor dos menos favorecidos, como compensação de seu infortúnio. Melhor do que discurso caberá ao professor os recursos da ternura. Ele deverá amar seus alunos, somente assim os ensinara a amar também. O menino conhece quando é amado, por que lê nos olhos e nos modos e se afeiçoa por quem se vê amado e protegido. Que esta benevolência do mestre acompanhe o menino até fora do circuito da escola. Se ele adoecer, que o professor o visite se for maltratado que interceda por ele, se tiver desgostos que seja consolado. E que esta doce influência continue. Que nada se despreze em ganhar a confiança dos alunos, pois que esta abre o coração e dispõe para a afeição.

“Amai-vos uns aos outros” (1839, p.192), propõe o autor por fim, para que esta seja a alma das relações nas escolas entre os alunos e aos professores. Algumas vezes os alunos poderão estar melancólicos, abatidos e desanimados sem motivo aparente; em outras, poderão estar em singular estado de irritação; as razões podem ser externas ou internas, as consequências do regime de vida em que estão acometidos. Porém, o professor se 
encarregará, quando lhe for possível, de conservar em seus alunos a serenidade, por esta ser condição indispensável à felicidade deles e do sucesso em seus estudos.

\section{Décima conferência}

Continuação da mesma matéria. - Como pode inspirar o Professor de Primeiras Letras aos discípulos o sentimento de seus deveres.

Segundo o Barão Degerando (1839), cabe agora aos mestres, depois de terem purificado as inclinações de seus alunos, desenvolverem neles a mais sublime das virtudes morais: a consciência - aquela voz interior que faz diferenciar o bem do mal e "revela a sagrada autoridade do dever" (1839, p. 200). Assim, seria um erro o mestre supor que esta tenra idade não seja capaz de ter o verdadeiro sentimento de dever, que só se deixam levar da autoridade e imitação. A voz da consciência só é ouvida no silêncio da reflexão. O que ocorre a estes meninos nada mais é do que distração e não falta de sentimento moral; é falta de exercício e não incapacidade. O momento em que entram na escola é o ideal para começarem com eficácia esta importante educação. Nesta idade já são capazes de diferenciar o que é digno de louvor e o que é digno de repreensão, se forem convenientemente dirigidos para isto. Portanto, cabe ao professor presidir as primeiras advertências pelas quais se ensina a consciência a se manifestar.

O autor compara a missão do professor ao do sacerdócio moral. O professor, segundo ele, poderá gravar com indeléveis caracteres as regras do dever nas alminhas de seus alunos. E propõe como fazê-lo ao desempenhar sua missão: enganam-se os que creem que seja apresentando aos alunos de modo geral e abstrato as regras da moral; é por se cometer este tipo de erro que os professores são injustos com seus alunos.

\footnotetext{
Anda a lei do dever impressa no fundo d'alma, o menino dará com ela logo que possa entrar em si. Ajudemô-lo a ler neste livro interior, preparemô-lo pelo sossego do coração e silêncio exterior para esta séria reflexão [...]. Tiremos esse exemplo da experiência a seu alcance: escolhamo-lo a princípio nas ações de que ele for imparcial testemunha, e ao depois nas que lhe dizem respeito. Façamos-lhe mais que tudo notar bem as intenções que as inspiraram, e as consequências por elas produzidas. Se lhes der conveniente atenção, não deixará de aprovar umas e condenar outras; de louvar ou repreender seus autores. (DEGERANDO, 1839, p. 202-203).
}

Mais adiante, deverá o professor tirar seus exemplos de suas ações, aguardando que o aluno a possa julgar com animo tranquilo. Assim, animado de franqueza e sincera boa fé, ele será feito juiz de si mesmo. Através destas práticas o professor conseguirá despertar em seus 
alunos a voz da consciência. Para tanto será preciso estabelecer com ele intima comunicação e, por conseguinte ter obtido sua confiança. Com objetivo de se cultivar a moral nos alunos, deve-se, ainda dar-lhes bons livros, para que através da boa leitura continuem a receber saudáveis instruções de moral. O autor continua propondo aos mestres para que apresentem aos discípulos imagens do bem, ensinando a virtude através de modelos da mesma virtude. Mostrando fielmente, lhes parecerá natural e amável e facilmente a seguirão.

Sobre a autoridade moral, propõe que seja bem conhecida dos discípulos. É preciso que esta seja nutrida no coração infantil, não sendo alterada com servilismo ou temor. É preciso fazer com que os alunos abracem e "amem a obediência, como justa e natural de sua fraqueza" (1839, p. 208). A autoridade arbitrária será dominação. A ameaça de castigo que não se justifica pelo erro cometido nada mais é do que violência; recompensa que não se fez por merecer é apenas favor. Ao professor, solicita-se que nunca use da autoridade nele depositada, senão em favor de seus alunos. Pois, quanto mais respeito tiver de seus alunos, tanto mais serão obedecidos.

Neste ponto da conferência, embora o autor diga que não repetirá as máximas encontradas nas obras de educação, ele coloca que é melhor recorrer aos estímulos dos prêmios do que a repressão das penas. Tanto os prêmios quanto as penas não devem ser frequentes a fim de não se enfraquecer sua eficácia. A aplicação de castigos não deve ser acompanhada de impaciência e cólera, mas deve ser pronunciada com serenidade; e todo castigo brutal deve ser severamente vedado. Punição e recompensa nãos devem ser nem muito precipitados nem muito demorados, mas sempre em tempo oportunos, e finalmente punindo ou premiando o menino, não se devem considerar os efeitos que procederam de sua ação, mas sim os motivos que o induziram a agir. $\mathrm{O}$ autor insiste na necessidade de manter o castigo e o prêmio como caráter moral com que munem a autoridade. O prêmio e o castigo nunca devem ser um fim que o menino aspire ou fuja, devem ser luz que os levem a refletir, ajudando-os a entrar em si mesmos e descobrir a razão do mérito ou demérito de suas ações.

\footnotetext{
Maus tratos, pancadas e de tudo quanto aterra a imaginação do menino, irrita-o e desanima-o sem que o ensine a cerca de suas faltas. Certas privações a propósito, sem que sejam cruéis, são custosas ao menino, dispõe-no a entrar em si, e sossegam sua agitação; imobilidade e solidão produzem particularmente este efeito. (DEGERANDO, 1839, p. 213).
}

Em certas ocasiões, apenas o elogio ou a repreensão, para meninos altivos bastarão para constituir a mola da disciplina. A advertência pode ser dada pelo mestre ou pelo condiscípulo, mas vinda do mestre tem maior peso pela superioridade do autor. Não convém abusar muito nem do elogio que poderia dar lugar a vaidade, nem da censura que poderia 
incitar a afronta. Devem-se dar indulgências às fraquezas humanas, em especial as dos meninos que se achegam as escolas dadas as suas idades e as circunstâncias em que estão. Deve-se desculpar o que apenas nasce da falta de experiência, leviandade e dissipação; e agir com rigor contra aquelas que denunciam astúcia, cálculo e hipocrisia: "Quando o menino somente obedece a algum hábito anterior, [...] ou quando ainda não pode adquirir hábito necessário, o justo é fornecer-lhe meios, do que tratá-lo severamente" (DEGERANDO, 1839, p. 215).

Pode haver prêmio perpétuo, mas que o castigo acabe logo que haja arrependimento, recomenda o autor.

\section{Undécima conferência}

Educação religiosa. - Parte que nela deve tomar o Professor de Primeiras Letras

Através da religião o homem se reconhece filho de Deus. A educação religiosa é necessária à infância, pois ensina ao menino a ser reconhecido e a ter confiança no ser Superior - regulador de seu destino. Ela protege a criança dos hábitos e paixões e do contagio dos vícios: "Conserva a paz do coração, o sossego dos sentidos, a serenidade do espírito, a retidão do juízo; abre assim caminho a razão, ao mesmo passo que conserva os penhores da felicidade" (DEGERANDO, 1839, p. 220). O menino andando na presença de Deus aprende a velar melhor sobre si mesmo, e faz com mais boa vontade o sacrifício que lhe é ordenado, oferecendo-o àquele de quem recebeu todos os bens. A educação religiosa é o mais poderoso auxilio para a educação moral dos discípulos. Estes melhor obedecem confiando na divina vontade, pontua o autor.

\footnotetext{
A religião é a primeira necessidade de todos; tem socorros especiais para todas as precisões, e utilidade relativa para cada estado de vida; necessária ao grande para preservá-lo do orgulho; ao rico para ensinar-lhe a moderação, e ao indigente para sustentar-lhe contra o abatimento e escudá-lo da desesperação. (DEGERANDO, 1839 , p. 222-223).
}

Conforme as palavras do Barão Degerando (1839), os discípulos encontrarão na religião novas forças, estímulos para seus esforços; e explicações sobre o mérito das provações a que são chamados; consolações para todas as suas penas. A religião é amiga dos pobres, e apresenta um futuro de felicidade aqueles que perderam as esperanças. Os professores precisam tomar uma medida preliminar, certificarem-se com os pais em que culto querem educar seus filhos. Não se pode esquecer que o professor deve atender como em tudo o mais, as condições que são requeridas pelas famílias. A confiança destes seria traída se 
fossem dadas direções contrárias à intenção de seus pais. Dessa forma, deve o professor absoluto respeito à profissão de fé religiosa do discípulo que recebe na escola. As verdades religiosas deverão ser mostradas de forma amável e risonha, própria para inspirar confiança e alegria e derramar serenidade no coração. Deve-se ensinar aos meninos a oração do coração, que exala em todos os momentos da vida; a respeitarem as práticas exteriores - de importância secundária - que são fórmulas expressões da religião, mas não era a religião. Candura, retidão, desempenho das obrigações devem ser sempre a melhor maneira de honrar a Deus.

\section{Duodécima conferência}

Como proceder o Professor de Primeira Letras no ensino dos Deveres.

A primeira recomendação proposta pelo Barão Degerando (1839) para ensinar os meninos aos cumprimentos dos verdadeiros deveres, consiste em evitar obrigações factícias. Não se deve dar ao menino um código de moral muito extenso, pois só o assustaria. Isto seria exigir uma forma de proceder para a qual ainda não estão aptos a aplicar. Cada coisa deve ser ensinada em tempo e lugar próprio. Pode-se se escolher algum preceito, alguma circunstância que traga ocasião natural para isso, que os faça entender sua aplicação, que experimentem os efeitos do esquecimento ou cumprimento de um dever.

A primordial tarefa do mestre para levar os meninos a perseverarem na virtude está baseada em três ações: preservá-los dos vícios que ainda não adquiriram e preservar a doce inocência típica dessa idade; corrigi-los de algum defeito que comece a aparecer, e que os avisos e conselhos sejam mais sérios caso o discípulo se recuse a segui-los e; finalmente instruí-los em seus deveres.

Os meninos começam a mentir por mero gracejo, depois acaba se tornando vício, fazendo-os perder o respeito à verdade. Nesta situação, a vigilância do professor deve aumentar, a fim de extirpá-lo logo que desponte. Deve-se por em primeira linha o dever da verdade e da sinceridade. Que o sucesso é recompensa dos que são fieis a verdade. $\mathrm{Na}$ sequencia, o autor segue discorrendo sobre as razões que levam o discípulo a mentir e que o professor terá que corrigi-los, mostrando que a franqueza e a retidão de caráter precisam prevalecer para que se tornem pessoas de bem.

A segunda ordem de deveres que se apresenta é que, aos meninos, deve-se ensinar a obrigação de respeitarem tudo o que for digno de respeito. Une-se a este respeito: piedade filial, veneração à virtude e a sabedoria, respeito e obediência aos mais velhos, submissão à 
autoridade pública, obediência a superiores e mestres, e respeito à ordem estabelecida. Contudo, há duas espécies de deveres: a negativa, que consiste em abster-se de tudo que possa prejudicar a sociedade; e a positiva, que consiste em servir a comunidade em tudo o que possa ser. As crianças são chamadas a desempenhar a primeira, mas podem ser gradualmente preparadas para conhecer a segunda, para satisfazê-los mais tarde, quando estiverem de posse de todas as suas forças.

Assim, de acordo com Degerando (1839), quando os meninos puderem entender sobre os direitos políticos, devem ser preparados para conceber sobre os direitos políticos. Não basta que conheçam as leis, é necessário que amem as leis de seu país, que não confundam interesses com direitos, pois ambição e vaidade tendem a fazer tomar por direito real os interesses que querem satisfazer.

\section{Décima terceira conferência}

Como trabalha o Professor de Primeiras Letras em fortificar o caráter dos meninos

Para o autor, o homem pode governar a si mesmo e a Educação Moral é responsável por preparar o menino para este tipo de governo. Os meninos que entram para a escola querem do mestre não que lhe prolonguem a infância, mas que os preparem para a vida adulta. Portanto, a educação primária deve ser uma espécie de escola moral onde o menino se acostume a lutar e vencer. Os alunos necessitam da força de caráter para serem capazes de moderação, e tanto mais necessidade dela terão, quanto mais forem destinados a sofrer privações. Há dois modos de receber as privações: uns a suportarão pela necessidade e pela violência, outros, as aceitarão voluntariamente pela moderação. Quem sofre privações contra a vontade está impaciente para se livrar delas; busca compensar-se de todas as maneiras possíveis, e apenas com olhos invejosos vê situações mais ditosas. Ao contrário, o segundo se consola do sacrifício, sabe abster-se de desejos, os quais as circunstâncias negam meio de satisfazer, ele está contente com seu estado, sua alma conserva sossego e serenidade, pois a força que o faz resistir às tentações e seduções é toda interna. Ensina a abster-se e não abusar. As progressões que a civilização tem introduzido na sociedade humana mostram que a modificação dos desejos conserva a paz pública e permite que a felicidade seja patrimônio de todos.

O autor coloca que é importante que essas crianças que vão para a escola e estarão aos cuidados do professor e logo se dispersarão pelos diversos caminhos da sociedade, aceitem a humilde condição que lhes cabe na vida. Para tanto a moderação será algo tão 
universal como indispensável. E só a conseguirão se aprenderem a domar-se. Pois, será muito mais fácil evitar fúteis ambições do que depois sarar delas. Os meninos depois que deixarem a escola e os cuidados do mestre sofrerão os reveses da vida, estarão expostos aos erros e injustiças, e cedo ou tarde perderão os afetos da família que os consolam na adversidade. Diante disso, será importante que sejam preparados, durante o tempo em que estiverem na escola, a sofrer com resignação as contrariedades, a não se deixarem arrebatar pela cólera, e não se deixarem abater pela tristeza. "Eles, por outra parte serão chamados à grande vocação de homens, de cidadãos, de franceses, (Brasileiros); alguns pediram serviços a pátria, talvez nas filas do exército de linha [...]" (DEGERANDO, 1839, p. 279).

Degerando (1839) responde a pergunta que ele mesmo se faz, sobre querer formar heróis com essa proposta de educação. Ele responde que quer formar heróis sim, mas heróis de um heroísmo desconhecidos no mundo. Heróis que lutem contra a própria sorte e dela triunfem por saberem vencerem-se a si mesmos. Neste lugar, os seres sabem abster-se, conhecem a simplicidade dos gostos e a constância dos esforços. Muitas virtudes ocultas reinam no meio desses homens laboriosos, que se contentam com pouco, não se queixam de sua sorte e nãos sentem inveja. A aquisição do caráter que esses meninos em tenra idade ainda não possuem, ocorrerá lenta e gradualmente, ainda que sejam breves as horas em que passem na escola para estudo, todas as circunstâncias durante esse período poderão ser aproveitadas para esse fim. Esta vigilância não deve intimidá-lo, deve ser sentida apenas como uma testemunha que o observa.

\footnotetext{
Aqui tendes por tanto um dos bons efeitos do Sistema Mutuo. Nele cada discípulo é conservado constantemente em ação, posto sob vela habitual e fácil, que nada tem de violento ou importuno. Os sinais dados são outros tantos estimulantes que o chamam a si, e o advertem do que devem fazer. Ele tem de ocupar um lugar, de desempenhar um papel. O monitor encarregado de abrir os olhos sobre seus condiscípulos deve primeiro que tudo saber observar-se a si mesmo. Depositário de uma porção de autoridade deve, para que o respeitem seus iguais, conter-se, domar-se e mostrar tranquilidade, circunspecto e ao mesmo tempo acautelado e atento. O Monitor voltando as fileiras dos simples alunos exercita sobre si mesmo o maior império, depois de haver mandado aos outros. (DEGERANDO, 1839, p. 285).
}

O autor aconselha ao futuro mestre que evite expor os alunos a impressões fortíssimas e afastar deles o que lhes possa causar terror e susto. Pessoas ignorantes costumam se aproximar destes meninos de tenra idade e causar-lhes medo com imagens de perigo a fim de sujeitá-los e contê-los. O mestre deverá livrá-los destas mentiras, esclarecerem-lhes a razão e restituir-lhes a segurança. Pois que "o homem em geral teme o que ignora" (1839, p. 287). 


\section{Décima quarta conferência}

Algumas molas da Educação. - Hábito e Imitação

Segundo o autor, o habito é uma disposição adquirida, que facilita a disposição de certos atos. O hábito exerce influências sobre os órgãos exteriores, sobre a percepção e a vontade e ocupa parte considerável nas três ordens da educação: física, intelectual e moral. O professor deve ter em vista o futuro do discípulo e atentar para que ele adquira agilidade, destreza e habilidade para trabalhos manuais; deve ainda, velar pelos passos, porte e postura do menino. Sendo que desta idade se adquirem hábitos que irão executar quase involuntariamente, podendo ser defeitos exteriores, que estão sujeitos a adquirir, e dos quais, depois, lhes será quase impossível se libertar.

O Barão Degerando (1839) compara os benefícios de se desenvolver hábitos de movimentos mecânicos com o corpo, com a obediência que o animalzinho domesticado atende a voz de seu dono, ao sinal acostumado, "a vista do Mestre, o assobio, a varinha do monitor imprimem em nossas escolas movimento geral e veloz em todos os exercícios dos discípulos" (1839, p. 295). Desta forma o professor encontrará meios para enfraquecer certos defeitos. Cura-se o menino da distração ao afastar dele os objetos que o levam a distrair-se. "Não basta, pois que o professor instrua, cumpre, além disso, que, por maior ou menor perseverança, com incansável paciência confirme a instrução pela conveniente repetição dos mesmos exercícios, de modo que o discípulo retenha o que houve aprendido" (DEGERANDO, 1839, p. 296). Geralmente os meninos se esquecem do que aprenderam, então, é útil repassar com eles, de tempos em tempos, as coisas que já estudaram para lhes refrescar a memória. A fim de ajudar o mestre e o discípulo neste trabalho, o autor propõe que se faça uso de combinações para ajudar sobre a recordação de ideias. Cita a cantoria como forma de conservar na memória as palavras cantadas. O professor antes de fazer o aluno decorar as lições deverá, primeiro, fazê-los entendê-las.

Conforme o autor, a educação dos meninos não se faz com as lições do mestre, mas sim com tudo quanto lhes chama atenção. Nisto está o poder da imitação sobre os meninos. Sendo estes naturalmente inclinados à imitação. A imitação concorre para tornar duráveis as tradições e os costumes, e, nas mãos dos professores, ela será ferramenta da qual poderá usar e abusar. Entre a lei da imitação e a lei do hábito há algumas relações: a imitação das ações dos outros tem o mesmo efeito que o hábito gera pela repetição. Fica mais fácil fazer o que vemos fazer. Assim, "a imitação é a segunda mestra da infância, ou melhor, a primeira, pela primazia de lugar, dada a superioridade de influencia" (1839, p. 310). É ela quase quem 
ministra, para o menino, a língua materna; pela imitação, herda os costumes daqueles com os quais convive. Entretanto, adota sem reflexão sem escolha todos os hábitos que o rodeiam. Por essa razão, os meninos dependem de seus pais e colegas muito mais do que dos professores. Portanto, aos professores pede o autor que trabalhem sobre as crianças mais com seus exemplos, suas ações do que por seus discursos.

\section{Décima quinta conferência}

Continuação da matéria antecedente. - Trabalho e Ordem

Degerando (1839) coloca que é preciso considerar que nunca é cedo para começar a educação do trabalho. Por ser o trabalho uma vocação natural do homem, já se trata de um elemento da educação. Para o menino o trabalho é um verdadeiro ensino, pois que lhe explica importantes verdades, uma vez que lhe recorda que a criatura humana não foi colocada sobre a terra para viver ociosa e estéril, mas sim para ser útil, através de ações fecundas e resultados duráveis. O professor de primeiras letras deverá começar esta importante lição para que o menino compreenda como o trabalho é o agente que produz bens, o fará notar nas operações do trabalho, a aplicação das faculdades de que o homem é dotado. O professor fará o discípulo perceber a íntima satisfação que sente a consciência depois de ter gasto um dia utilmente. Em geral, as pessoas mostram para os alunos o trabalho como sendo um cálculo, mas segundo o autor, nestas escolas, o trabalho deverá ser entendido como virtude. A ociosidade deverá ser desprezada e o trabalho exaltado. Desse modo, ensinar desde cedo aos meninos o gosto para o trabalho é muni-los contra o tédio, a miséria, a desordem e os vícios. O menino ocioso não tendo o que fazer se tornaria incapaz e cairia numa espécie de idiotismo e se ceder a natural inclinação de sua idade, acabaria entregue em uma desregrada agitação, que prejudicaria a si mesmo e aos outros. Seria pouco agradável, para quem observa ver estes meninos, por descuido de seus pais, deixados o dia todo em lugares públicos, em vadiagem, desperdiçando um tempo importante para a construção de um futuro melhor.

Degerando (1839) acredita que dar desde cedo o gosto ao trabalho aos meninos os dotaria de novas forças, os prepararia para novos adiantamentos, e daria novo desenvolvimento a sua educação física, intelectual e moral.

O trabalho manual, quando contido em justos limites e com as convenientes condições relativas a saúde, é excelente regimento higiênico, só por ser exercício regular e constante; porque favorece todas as funções dos órgãos da vida. Se certos ofícios totalmente sedentários são opostos a saúde, não é o trabalho que neste caso prejudica, mas a circunstância que o acompanha. (DEGERANDO, 1839, p. 320). 
No trabalho manual supõe também o uso da inteligência. $O$ professor deveria se aplicar em fazer intervir no exercício da atenção outras faculdades do entendimento para aperfeiçoar o mesmo trabalho. Os professores deveriam também, tanto quanto for possível, combinar nos meninos, trabalho do corpo com o trabalho do espírito, pois que estas duas ocupações alternadas simultaneamente seriam prodigiosas colaborações uma para com a outra. Os mestres precisam despertar em seus discípulos esse espírito de indústria, "que se ensina a fazer com perfeição o que se faz; que desenvolve atividade e cria recursos, multiplicam meios, inventa, aperfeiçoa, e do qual, seja qual for sua profissão algum dia, colherão muitas utilidades no decurso da vida" (1839, p. 322). Convirá que se cuide graduar as dificuldades destes meninos, não lhes pedindo outros esforços além de suas possibilidades, mas seguindo sempre progressivamente. Esta espécie de educação da indústria é uma importante prática para os meninos que frequentam as escolas de primeiras letras, da qual poucos são os mestres que se ocupam dela.

O professor dando ao discípulo o gosto e hábito pelo trabalho lhe ensinaria a bem trabalhar, ou seja, a fazer cada coisa com método, a trabalhar com perseverança, a acabar e a aperfeiçoar, adestraria as mãos, aprenderia a comparar uma obra imperfeita de um oficial um produto acabado e bem feito. Assim, o professor faria com que o aluno notasse que o bom método de trabalhar dobra as forças do trabalhador, poupando-lhe a fadiga. Dar aos meninos o gosto pelo trabalho é dar-lhes a melhor direção de suas faculdades morais, formando-lhes o bom costume e no ministério de muitas virtudes. O trabalho e a ordem são professores mudos, benfeitores da infância. A ordem de acordo com o autor classificaria, distribuiria e regularia cada coisa, sendo oposta à confusão e ao acaso. Sendo eminente conservadora, uma vez que para preservar as coisas de destruição e fazer com que durem seria preciso colocá-las em ordem; desejando achá-las quando delas se necessitar há que se arrumá-las; para poupar tempo - um dos mais preciosos tesouros, e se ordenar o emprego dos momentos e a distribuição do dia. Assim, a ordem, governa a lógica, e ajuda os meninos a bem julgar; forma-lhes a razão, e aponta-lhes os caminhos em que sua instrução deverá ocorrer.

Diante disso, o autor recomenda aos professores de primeiras letras a organizarem suas escolas segundo uma ordem material agradável aos olhos; que incitem seus discípulos a estabelecerem e conservarem a boa disposição de todas as coisas, a distribuição pelos lugares e tempos convenientes. Também pede que façam seus alunos notar a utilidade que tiram da prática da ordem em cada circunstância da vida. E para que ganhem gosto pela ordem não há melhor coisa do que o sentimento do belo. O professor deverá fazer as boas escolhas de 
modelos para os meninos; desenvolver neles o sentimento de amor da verdade e respeito às leis da moral.

\section{Décima sexta conferência}

Últimos conselhos aos Mestres de Primeiras Letras

$1^{\mathrm{o}}$ - Os professores devem estudar bem os meninos, quer as disposições pertinentes as suas situações e idade, ou às disposições individuais que constituem as variedades dos espíritos. Não devem fazer o mesmo juízo a respeito de todos, nem medir a todos pela mesma medida; alguns possuem excessiva viveza e precisam ser acalmados e moderados, enquanto que outros estão entregues a hábitos de moleza e desleixo e necessitam ser despertados. Estas disposições logo se anunciam aos olhos do professor experiente e observador.

$2^{\mathbf{o}}$ - Os professores devem dar aos meninos ideias justas de felicidade; protegê-los das numerosas ilusões a que os expõem as impressões dos sentidos. Devem ensiná-los a gozarem dos bens que estão ao seu alcance, a desfrutarem as verdadeiras alegrias dadas pela providência divina, que são alegrias de maior valor por serem alegrias comuns.

$3^{\circ}$ - Os professores devem fazer pelos meninos todo bem que puderem para muni-los de provisões necessárias a toda uma vida, visto que, o tempo em que mestre e discípulo ficam juntos costuma ser muito curto e passando muito rápido. $\mathrm{O}$ melhor modo de poupar tempo será trabalhar com perseverança e método, para não precisar voltar atrás e repetir as mesmas coisas.

$4^{\circ}$ - Não posso separar-me de vós, amados Ouvintes, sem que de novo vos convide, a que empregueis todos os meios que estiverem em vossas mãos, para manter a concórdia entre os membros da familiazinha de que cada um de vós tem de ser cabeça. Fiquem esquecidas fora do limiar da escola às diferenças de idade, condição, profissão e fortuna [...]. (DEGERANDO, 1839, p. 339).

$5^{\circ}$ - Os professores devem bem organizar suas escolas, como meio de estabelecerem sua autoridade e conservarem a boa ordem e estabelecer entre os discípulos troca de mútuos socorros. Na formação das classes devem multiplicar os círculos dos meninos, de forma que reúnam em cada operação somente os alunos aptos a executá-las; graduando essas classes e essas divisões de modo, que a escala de progressão não se interrompa, e que as escolhas de Monitores deem ocasião de empregar alternadamente os alunos que a merecem, a fim de que se estabeleça entre eles generosa emulação. 
$6^{\circ}$ - Parte menos essencial das obrigações do mestre que se exercita fora da escola, pela ação individual do mestre sobre cada discípulo. Esta parte é ignorada pela maioria dos professores e se torna a mais importante porque nos sistemas adotados nas escolas impede relações mais diretas entre alunos e professores como ocorre, por exemplo, no método do ensino mútuo.

\footnotetext{
Em práticas particulares como cada menino aprenderia do professor a bem conhecer as ocultas disposições daquele, a obter sua confiança, a ler-lhe no fundo do coração, a dar-lhe avisos, consolações e estímulos, a esclarecê-los a respeito de suas faltas e a relevar-lhas. Não se limita o ministério do professor a ser guarda da escola, mas a dar em sua pessoa a cada estudante um pai adotivo e verdadeiro amigo. (DEGERANDO, 1839, p. 340-341).
}

$7^{\circ}$ - Os professores devem ensinar também, além de ler, escrever, contar e desenhar, noções de economia doméstica e higiene através de elementos simples e familiares. Dessa forma, os alunos melhor conceberão estes conceitos, pois não serão apresentados como doutrinas, mas em certo modo nascerão das circunstâncias.

$8^{\circ}$ - Os professores devem conquistar a confianças dos pais de seus alunos para obter auxílio em suas intenções, mas ao mesmo tempo devem manter sua dignidade e independência. Em relação aos mais desafortunados devem mostrar benevolência.

$9^{\circ}$ - Os professores devem ser criteriosos nas escolhas das amizades e não tomar partido em desavenças nem em mexericos.

$10^{\circ}$ - Os professores devem evitar se colocarem em dependência muito absoluta dos ministros da religião (em relação ao ensino religioso).

$11^{\circ}$ - Deveres legais - sujeitam o professor especialmente ao governo.

$12^{\circ}$ - Propõe ao professor a confecção de um livrinho (documento) para cada aluno onde registraria quando entrou na escola, quando saiu, seu adiantamento, sobre seu temperamento, e o que puder interessar em sobre sua saúde.

$13^{\circ}$ - Os regulamentos das Escolas de Ensino Mútuo ordenam que os professores façam listas dos discípulos. Os professores que não tiverem adotado este método de ensino devem ao menos seguir este exemplo. Estas listas devem atestar frequência dos alunos, mostrarem seu adiantamento nos diversos estudos, e aconselha o autor, que ajuntem notas particulares sobre as disposições e caráter de cada menino.

$14^{\circ}$ - Os professores ao mesmo tempo em que instruem, devem continuar se instruindo, sem interrupção.

$15^{\circ}$ - Os professores devem recorrer a algum amigo (próximo ou distante) quando estiverem em dúvida quanto suas resoluções. 
$16^{\circ}$ - Os professores devem estabelecer conferências entra cada comarca para comparar modos de proceder e comunicar experiências individuais.

$17^{\circ}$ - Os professores devem limitar suas despesas de acordo com os seus rendimentos.

$18^{\circ}$ - Salas de Asilo - são escolas de criancinhas. Preparam o aluno que vem para suas escolas com melhores disposições.

$19^{\circ}$ - Fundação das Escolas de Domingo para os moços que já terminaram seu tempo na escola, para prolongar as relações que tiveram com o professor e ainda receber deles alguns conselhos.

$20^{\circ}$ - Não confundir as Escolas de Domingo com as classes de aperfeiçoar que tem um fim especial - destinadas a certo número de meninos que já andam na escola ordinária e aos que dela saíram a fim de dar maior grau de instrução aos alunos que desejarem, talvez não seja suficiente para alunos com maiores capacidades intelectuais, então, o professor poderá abrir para eles, no intervalo das lições ordinárias ou à noite, uma classe particular, reservada para esta ordem superior de ensino.

$21^{\circ}$ - São escolas destinadas aos adultos que na infância não puderam receber a instrução elementar. Os professores podem abrir um estabelecimento desta natureza para completar seu honroso ministério. Nestas escolas o ensino será mais rápido, acomodando-se a idade dos sujeitos.

$22^{\circ}$ - Os professores de primeiras letras nãos precisam formar oradores, mas devem formar sujeitos que saibam exprimir seus pensamentos, falar a sua língua e entenderem o que dizem. Para isto devem mandar seus alunos escreverem alguma composição cujas ideias sejam tiradas de suas leituras, suas relações habituais para que se acostumem a dar conta de suas ideias e a exprimi-las com clareza.

$23^{\circ}$ - Se empenhar em fazer o melhor.

$24^{\circ}$ - Aconselha-se ao professor formar um círculo de leitura.

$25^{\circ}$ - Não basta saber escolher livro, mas também saber lê-los. Para ensinar esta arte aos discípulos: convém ler com atenção, refletir, comparar, classificar, resumir no próprio espírito, tirar de cada obra a substância que a encerra. Assim, devem os professores guiar os alunos a fazerem o mesmo, interrogando-os sobre o que tiverem lido.

Abaixo seguem as obras apontadas, estando divididas em três partes:

$1^{\circ}$ - para uso pessoal do professor;

$2^{\circ}$ - destinada aos meninos que frequentam suas escolas;

$3^{\circ}$ - só para adultos. 
O Barão Degerando (1839) indicava para uso pessoal do mestre de primeiras letras a leitura das seguintes obras, compondo assim uma biblioteca:

1 - Obras que direcionem moralmente o professor;

2 - Obras que lhe deem métodos de ensino;

3 - Obras que lhe deem instrução sobre a ordem de conhecimentos, que possam fazer parte de seus estudos.

Há a indicação de dois livros:

1 - Tratado da Educação dos Meninos (Locke).

2 - Tratado d'Educação Pública considerada em suas relações com o desenvolvimento das Faculdades, adiantamento da civilização e atuais necessidades de França (M. Naville). - Obra completa, que bem mostra as relações da instrução e educação.

Sendo o professor casado e sua esposa professora de meninas, um livro é indicado para elas e que pode ajudar muito na educação de meninos também: Tratado de Fenelon sobre educação de Meninas.

Por último é indicado o Manual do Professor de Primeiras Letras. Este abrange, ao mesmo tempo, educação física, intelectual, moral e religiosa; contem lista de livros para uso do próprio professor e dos alunos. Numa palavra, é um verdadeiro manual.

Outro Manual indicado possui o mesmo título do anterior (Manual do Professor de Primeiras Letras). É tradução de uma obra alemã, publicada em 1824 e teve muita aceitação na Alemanha, Holanda e Bélgica. Será muito útil ao professor e nele poderá encontrar meios de melhorar os meninos e formá-los na virtude.

Quanto ao método de ensino o Barão Degerando (1839) sugere: O Systema de Ensino Mútuo.

\section{REFERÊNCIAS}

BASTOS, M. H. C. A formação de professores para o ensino mútuo no Brasil. In: FARIA FILHO, L. M.; BASTOS, M. H. C. (orgs.). A escola elementar do século XIX - o método monitorial/mútuo. Passo Fundo: Ediupf, 1999, p. 238-269.

CASON, Silvia Regina. O ensino mútuo: uma inovação pedagógica do século XIX. MENEZES, Maria Cristina (Orientador). Campinas, [SP: [s.n.], 2011. CD ROM. ISBN (Broch.). Disponível em: <http://www.bibliotecadigital.unicamp.br/document/?down=000785242>. Acesso em: 5 dez. 2015 . 
CURSO NORMAL. Para Professores de $1^{\mathrm{a}} \mathrm{s}$ letras ou Direções Relativas a Educação Physica, Moral e intelectual. Nas Escolas Primárias, Pelo Barão Degérando, Impresso por ordem do Governo Provincial do Rio de Janeiro. Para uso dos Professores, Traduzido e acrescentado com um apêndice de Leis Gerais e Provinciais. Sobre escolas, pelo Dr. João Candido de Deos e Silva. Nictheroy. Typographia Nictheroy de M.G. de S. Rego, Praça Municipal. 1839, 421p.

HISTÓRIAS e memórias da educação no Brasil. 3. ed. Petrópolis: Vozes, 2009.

NUNES, Clarice (Coaut. de). O passado sempre presente. São Paulo, SP: Cortez, c1992, 85p. (Questões da nossa época, v. 4)

VILLELA, Heloisa de Oliveira Santos. A primeira escola normal do Brasil: uma contribuição a historia da formação de professores. 1990. 286f. Dissertação (mestrado) Universidade Federal Fluminense, Centro de Estudos Sociais Aplicados, Niterói, RJ.

O ensino mútuo na origem da primeira escola normal do Brasil. In: FARIA FILHO, L. M.; BASTOS, M. H. C. (orgs.). A escola elementar do século XIX - o método monitorial/mútuo. Passo Fundo: Ediupf, 1999, p. 145-175. 